\title{
The Policymakers' Dilemma: Change, continuity and enduring RATIONALITIES OF ENGLISH PENAL POLICY
}

\section{Harry Annison}

\author{
Southampton Law School
}

Accepted Version

This is a pre-copyedited, author-produced version of an article accepted for publication in the British Journal of Criminology following peer review. The version of record is available online at https://academic.oup.com/bjc DOI 10.1093/bjc/azx066

\section{Introduction}

This article contributes to the important, and under-researched, ${ }^{1}$ issue of the beliefs and practices that underpin and sustain penal policymaking in specific contexts. In particular, it explores how 'external' structural change is interpreted, rationalized and thereby instantiated by penal policymakers. It does so by analysing a distinctly unusual period in peacetime British history: the five years of formal coalition government from 2010, comprising the Conservative party and Liberal Democrats.

Drawing on in-depth interviews with senior penal policymakers, I analyse how these policymakers sought to manage the uncertainties of this period. I explore how the dilemmas posed by the need to develop penal policy within an explicit coalition framework intersected with those presented by the need to operate within dramatically

\footnotetext{
${ }^{1}$ There are, of course, some notable exceptions, some of which are discussed below.
} 
reduced budgets (the 'austerity agenda'). We see that policymakers' responses involved both political parties seeking to 'make coalition work' and to 'balance the books', and saw civil servants (therefore) working, as one official put it, to 'reformalize the arrangements'.

We see that the actions taken in response to these dilemmas tended, in some regards, to improve deliberation and restraint in penal policymaking. However, policymakers' actions in taming the dilemmas posed by coalition served ultimately to strengthen underlying biases towards centralization and exclusion. The analysis presented therefore demonstrates the durability of exclusionary rationalities within English penal policymaking. It is argued that this is not because they are pre-ordained, an inevitable consequence of external change; rather they are the emergent properties of situated agents responding to novel circumstances and attendant ideas. The 201015 coalition had 'shallow roots'; policymakers grasped for what they already knew in order to contend with this novel situation.

The article begins by situating the research within the context of debates regarding the relationship between political economy, political systems and penal change. The interpretive approach, and related methodology is then set out. I then survey the key developments and relevant context of the 2010-15 government, in order to identify questions that propel the subsequent analysis.

The ways in which policymakers confronted the dilemmas posed by coalition are then explored. Three themes are set out: deliberation, restraint and exclusion. These are utilised as heuristic devices to structure analysis of the policymaking rationalities that crystallized during the coalition period. In conclusion, I address the more general lessons this study provides regarding the relationship between 'external' factors, 'internal' policymaking rationalities, and penal change. 


\section{Understanding Penal Policymaking under Coalition Government}

In order to consider the effect of coalition government on penal policymaking, we can usefully begin with works that have addressed the relationship between penal change and political economy (Reiner, 2017). Scholars such as Cavadino and Dignan have explored the relationship between variations in political economy and levels of punitive cultures and practice (Cavadino and Dignan, 2007). Others have focused centrally on the relationship between neoliberal political economy and punitiveness (Bell, 2011; Wacquant, 2009).

Lacey has extended, explored and challenged this literature by insisting on the important role of political systems (ie systems of election and governance) in mediating the relationship between political economy and punitiveness (Lacey, 2008). Lacey argues that in first-past-the-post systems, and particularly in present postideological conditions (cf Loader, 2008), political parties become 'increasingly focused on the median voter', leading to the 'unmediated responsiveness of politics to popular opinion in [an] adversarial context' (Lacey, 2008: 76). Being 'tough on crime' is thus highly appealing, allowing politicians to appear to resolve complex issues by way of simplistic and satisfyingly ‘tough' criminal policy (Lacey, 2008: 71).

Lacey suggests that, by contrast, nation states underpinned by proportionally representative electoral systems tend to prioritize co-operation and feature numerous checks and balances (Lacey, 2008: Chapter 2). Under such systems, coalition government is the norm. Bargaining and nuanced debate over appropriate responses to complex policy issues is de rigueur; all of this is likely to make penal populism easier to resist (Lacey, 2008: 76). 
This is a plausible argument, supported by detailed statistical analysis. This article, however, shares Lacey's own reluctance to reduce the complex dynamics of penal policy to a straightforward unidirectional relationship between a small number of structural 'inputs' and penal policy 'outputs' (Lacey, 2012). In a more recent development of the 'prisoners' dilemma' argument, Lacey recognises that the impact of coalition is not only dependent upon its broader 'institutional and cultural environment' (Lacey, 2012: 225), but also on the 'nature, strategies and internal dynamics of the parties' (Lacey, 2012: 234).

We move, thus, to a recognition of the centrality of politics to penal change (Loader and Sparks, 2004; Annison, Forthcoming). Existing contemporary analyses of political dynamics and their relationship with penal policy together form a small but important body of literature. To take some notable examples, Loader has provided a critical reconstruction of the 'disposition towards the governance of crime' that predominated during the middle decades of the twentieth century (Loader, 2006). Rogan has analysed the role of politician-senior civil servant relationships in informing developments in prison policy (Rogan, 2011). Rock has provided a valuable account of the political interactions leading to the 'construction' of victims' rights in England and Wales (Rock, 2004). Jones and Newburn - and more recently Ogg - have explored the role of policy transfer as a policymaking dynamic (Jones and Newburn, 2007; Ogg, 2015).

It is, further, possible to identify a small number of accounts that trace penal policy development by coalition government in different national contexts, including New Zealand (Pratt and Clark, 2005), Scotland (McAra, 2008) and England and Wales (Lacey, 2012; Skinns, 2016). While such works provide important analysis of developments in these specific locales, empirically-informed insights into the internal 
political dynamics that underpin such policy developments (and in particular those based on first-hand accounts) remain rare.

This article addresses this lacuna, analysing specifically the ways in which coalition government shaped penal policy in a first-past-the-post context. In order to do so, this paper draws on 26 in-depth semi-structured interviews with senior policymakers, conducted between March 2014 and August 2016. Respondents comprised: eight senior civil servants (CS); four Conservative political actors (Con); five Liberal Democrat political actors (LD); six charities, campaigners, and other policy participants $(\mathrm{Ch})$; and three other parliamentarians involved in criminal justice policy $(\mathrm{Pa}){ }^{2}$ The change of government, and the fact of coalition, ensured that a variety of policy participants including both longstanding participants and relative newcomers were interviewed. ${ }^{3}$

Respondents were selected due to their involvement with penal policy during this period. A particular effort was made to interview civil servants, parliamentarians, NGO representatives and other policy participants who, notwithstanding their potentially lower visibility compared to some political actors, tend to play important roles in the type of policy processes being explored (Rogan, 2011). Triangulation utilizing contemporaneous records (policy documents, Hansard and so on) and other subsequently published accounts of the time (including autobiographies and interviews) strengthens the analysis presented.

\footnotetext{
${ }^{2}$ Interviews lasted an average of 60 minutes. Twenty-one were recorded and transcribed; for the remaining five contemporaneous handwritten notes were taken and typed-up shortly after the meeting. A small number of quotes have been amended to ensure a level of anonymity in accordance with ethical assurances provided to interviewees. For further discussion of the utilization of 'elite interviews' as a criminological research tool, see Annison (2015: Appendix I).

${ }^{3} \mathrm{We}$ address, in other words, what Flyvbjerg has termed an 'atypical' case study. Such cases tend to 'reveal more information' because of the 'activation' of more actors and mechanisms in the situation studied (Flyvbjerg, 2006: 229).
} 
In order to analyse penal policymaking, I collate and amalgamate 'narrative explanations' (Wagenaar, 2011) provided by policy participants of this period in penal policy, thereby exploring the rationalities and practices relied upon by relevant actors (Bevir and Rhodes, 2010) . This interpretive account is explanatory in that the stories provided offer insights into 'the conditional connections that link people, events and ideas to one another and [thereby] explain actions and practices' (Rhodes, 2011: 7). ${ }^{4}$

This article speaks of 'dilemmas'. These are ideas, or perceived changes to the landscape, which by challenging the beliefs or established rationalities of a group (either by directly confronting them, or by making them appear no longer tenable), pose a problem. Such problems must be resolved, either by the accommodation of the new ideas within existing beliefs and practices (by which process the new ideas are themselves to some degree transformed), or by rejection of the new ideas and a reaffirmation of existing ideological and practical frameworks (Bevir and Rhodes, 2010). We can thus usefully speak of the dilemma of coalition.

In speaking of policymaking 'rationalities', I point to 'the ways in which governments and other social actors draw on knowledge to construct policies and practice' (Bevir and Rhodes, 2010: 96). This involves conscious knowledge and tacit assumption. It can relate to a specific policy area (broad assumptions about the nature of policy in an area, about appropriate sources of knowledge, and so on) or about policymaking more generally (how are things done around here?). At the level of the individual actor, it therefore speaks to how actors 'do' policymaking: the practices and assumptions that may be in play in a particular setting (Wagenaar, 2011: chapter 3). Specific meanings of coalition (or other 'external' factors) therefore emerge from

\footnotetext{
${ }^{4}$ For detailed discussion of the theoretical and methodological framework utilized here, see Annison (Forthcoming).
} 
the interactions between individual actors, drawing on (and potentially reshaping) existing rationalities (Wagenaar, 2011: 61).

Before exploring these narrative explanations of this period, and the policymaking dynamics therein, we can first orient ourselves by surveying briefly the key developments, and relevant context, of the 2010-15 government.

\section{Setting the Scene: Penal Policy and the 2010-15 UK Coalition}

The 2010 UK General Election resulted in the first hung parliament since 1974: no party achieved an overall majority in the House of Commons. A formal ConservativeLiberal Democrat coalition emerged, the first peacetime coalition since the 1930s. This was underpinned by three key documents: an Interim Coalition Agreement, a Programme for Government and a Coalition Agreement for Stability and Reform. Crucially, it was buttressed by the establishment of five-year fixed-term parliaments, designed to make an early general election highly unlikely. ${ }^{5}$

The Conservative Party and Liberal Democrats were not obvious coalition partners. Although damaged by the years of New Labour rule, most Liberal Democrat MPs and members nonetheless tended to regard themselves as left of centre (and therefore more natural bedfellows with the Labour Party). The Conservatives, by contrast, remained a party of the right. While some liberalisation of social policy was proposed, swift and swingeing cuts to public spending were set out in 2010 that would (and were designed to have) dramatic implications for the welfare state (Quinn et al., 2011: 300). These went far beyond the measures accepted as necessary by the other two major parties.

\footnotetext{
${ }^{5}$ The 'snap' election of 2017 has demonstrated the limits of this Act in a single-party government context.
} 
The Liberal Democrat leadership, though headed by 'Orange book' economic liberals who were open to co-operating with either party, ${ }^{6}$ were sceptical about being able to extract concessions from the Conservative party on their key demand for electoral reform. The Liberal Democrats had long argued that proportional representation, which tends to result in multi-party coalition government, should supersede first-past-the-post as the electoral system for UK general elections. On the other side, many Conservatives wished to rule alone as a minority government. While Conservative Party leader David Cameron had sought to 'modernize' the Conservative party and soften its image (Seldon and Snowdon, 2016), fundamental ideological divisions appeared to remain between the Conservatives and the other two parties.

Surveying the broad political landscape, the era of two party politics in the United Kingdom seemed potentially to have passed, with the rising popularity of parties such as UKIP, the SNP and the Green Party joining the Liberal Democrats on the scene. Notwithstanding the heavy bias towards single-party government under the first-past-the-post electoral system, it appeared that hung parliaments - and the possibility of further coalitions (be that formal coalition or more informal arrangements) - might not be an aberration.

The Conservative-Liberal Democrat coalition government followed 13 years of (New) Labour rule, a period that prompted sharply diverging critical evaluations. For some, significant improvements were made to penal life and prison conditions. For others, Labour had become bound up in a penal arms race of their own making (Silvestri, 2011). A burgeoning managerialist culture underpinned an ongoing punitive drive (Randall, 2004). In 2010 the prison population of England and Wales

\footnotetext{
${ }^{6}$ The term 'Orange book' liberal is widely used as shorthand for Liberal Democrats arguing for a return to classic notions of economic liberalism (Marshall and Laws, 2004).
} 
stood at over 85,000, double that of 1991 (Allen and Dempsey, 2016: 3-4). Taken together, these dynamics placed the penal system under chronic stress, periodically flaring into crisis (Bastow, 2013).

There were some hopes in 2010 that the altered economic landscape and the exhaustion of the New Labour political project might lead to a reconsideration of this trajectory. Indeed, the Conservative party's 2008 policy paper set out a vision of fundamental and 'joined-up' reform of the criminal justice system, prioritizing devolution, rehabilitation and the utilization of 'innovative' incentive methods such as payment by results. All of this was to be underpinned by, and to demonstrate, the 'compassionate conservatism' that supporters argued was at the heart of the Cameron project (Seldon and Snowdon, 2016). ${ }^{7}$

Hopes for a change of course were bolstered when veteran Conservative MP Kenneth Clarke was appointed as Justice Secretary, joined by a ministerial team mostly comprised of other Conservative MPs. On the Liberal Democrat side, veteran Lord (Tom) McNally was appointed junior minister in the Ministry of Justice. Liberal Democrat Leader, and Deputy Prime Minister (DPM) Nick Clegg headed a Home Affairs Committee in Cabinet, which oversaw policy areas including criminal justice.

Within weeks of his appointment, the Justice Secretary made clear his desire to halt the populist tone and 'prison works' mantra that had prevailed from the early 1990s. The near-doubling of the prison population in 20 years was 'ridiculous' (Stratton, 2010). This was a 'once in a generation opportunity' to 'make a new start' in penal policy (Blunt, 2010). Locking up more people for longer was a 'discredited numbers game' that was 'simply unsustainable' (Herbert, 2010).

\footnotetext{
${ }^{7}$ The policies were, of course, contested and highly contestable; see, for example, Downes and Morgan's concern that behind the 'Big Society' lurked the 'Big Market' (Downes and Morgan, 2012: 194).
} 
Lacey neatly summarized the central policy goals of the Clarke era thus:

To abandon the Labour government's extensive prison building programme; to implement sentencing reform to reduce the use of imprisonment for less serious offences; to place greater emphasis on constructive prison regimes and on work in prisons; and to develop local partnerships and programmes geared to reducing recidivism, including the institution of results-based funding for service-providers from the private and voluntary sectors (Lacey, 2012: 204). ${ }^{8}$

These positions echoed much of 'Prisons with a Purpose' (Conservative Party, 2008) and aligned well with the Liberal Democrats' longstanding concerns with the levels of imprisonment and the ratcheting up of sentencing policy that had driven this trend (Liberal Democrats, 2010: 74).

The initial drive for penal reform, including moderation in sentencing, bore some fruit in the Legal Aid, Sentencing and Punishment of Offenders Act 2012. The discredited Imprisonment for Public Protection (IPP) sentence was abolished (Annison, 2015); the Act sought to limit what many campaigners regarded as the unnecessary use of custodial remand; it increased court powers to impose suspended sentences; and to simplify elements of sentencing law and rules relating to prisoner release on licence. In the face of substantial pressure from Conservative MPs, magistrates' sentencing powers were not increased. Penal reformers cautiously welcomed the direction of travel (Downes and Morgan, 2012: 192-195).

However, the reductionist wings of the legislation had been clipped by the time of its passing into law. Proposals to increase discounts for early guilty pleas were disavowed (Cameron, 2011). Provisions to 'balance' the legislation were introduced: 'tough' measures such as 'mandatory' life sentences for repeat serious offenders and,

\footnotetext{
${ }^{8}$ See 'Breaking the Cycle' consultation paper (Ministry of Justice, 2010).
} 
indeed, the very inclusion of the term 'Punishment of Offenders' in the legislative title (Clarke, 2016: chapter 24).

In September 2012, a cabinet reshuffle saw Ken Clarke replaced as Justice Secretary by Conservative MP Chris Grayling, with changes also to the Conservative ministerial team. In December 2013, Simon Hughes superseded Lord McNally as the Liberal Democrat minister in the Ministry of Justice. We had therefore, in terms of personnel, a 'Clarke era' lasting nearly half the fixed-term parliament, followed by a 'Grayling era'.

These personnel changes corresponded with a significant shift in tone and policy emphasis. It was clear that the Grayling era was intended to achieve two - and only two - goals: to bolster the Conservative Party's 'tough on crime' credentials in the run-up to the 2015 General Election and to drive through a fundamental reorganization of probation activities along market lines (Garside and Ford, 2015). 'Tough' speeches, proposals and policies were made with regularity. Legislative measures served inter alia to increase the force householders could use in responding to a burglary $;^{9}$ extend the minimum length of extended sentences for dangerous offenders; ${ }^{10}$ expand the range of offences for which a mandatory life sentence must be imposed; ${ }^{11}$ restrict the use of cautions; ${ }^{12}$ and introduce a minimum sentence for a second offence involving an offensive weapon. ${ }^{13}$

The Incentives and Earned Privileges (IEP) scheme was hardened to make prison suitably 'austere' in the eyes of the Justice Secretary. A 'criminal courts charge' was introduced, compelling judges to impose additional charges on

\footnotetext{
${ }^{9}$ Crime and Courts Act 2013, s43

${ }^{10}$ Offender Rehabilitation Act 2014, s8

${ }^{11}$ Criminal Justice and Courts Act 2015, s1

${ }^{12}$ Criminal Justice and Courts Act 2015, s17

${ }^{13}$ Criminal Justice and Courts Act 2015, s28
} 
defendants, taking no account of their (in)ability to pay. ${ }^{14}$ The 'Transforming Rehabilitation' project was irreversibly implemented before the 2015 General Election (Skinns, 2016: chapter 6).

The coalition period left in its wake a policy landscape that constituted for Skinns a 'turbocharged' form of the punitive managerialism that had emerged over previous decades (Skinns, 2016). Emerging evidence about the harm caused, and dangers posed, by policy decisions from this period show prisons increasingly becoming 'unacceptably violent and dangerous places' (HM Chief Inspector of Prisons, 2017), while the performance and viability of the probation service causes significant concern (see for example HM Inspectorate of Prisons and HM Inspectorate of Probation, 2017).

This sketch of developments during the 2010-15 raises a number of questions. What policymaking dynamics propelled the policy measures noted above? What rationalities did policymakers draw upon in responding to the specific dilemmas posed by the period? How, in particular, was coalition understood and acted upon by penal policymakers?

In order to address these questions, I now present a critical reconstruction of penal policymaking during this period, drawing on the in-depth interviews conducted with policy participants. I consider first how the key dilemmas were experienced, before training our focus on three concepts that capture emergent themes of the period: deliberation, restraint and exclusion.

\footnotetext{
${ }^{14}$ Prosecution of Offences Act 1985 (Criminal Courts Charge) Regulations 2015
} 


\section{Taming the Dilemmas of Coalition}

Coalition prima facie significantly challenged the partisan, combative, winner-takesall culture of British politics. It was not clear that existing beliefs and practices, based on assumptions fostered through decades of oppositional politics, would continue to serve politicians well (Hazell and Yong, 2012).

Most immediately, it complicated party management efforts that are always in play in the early days of a new government. Kenneth Clarke's appointment as Justice Secretary was one result of these altered dynamics, his anticipated Business Secretary post being given over to the Liberal Democrats. The possibly apocryphal tale of his selection for the post was retold by several respondents:

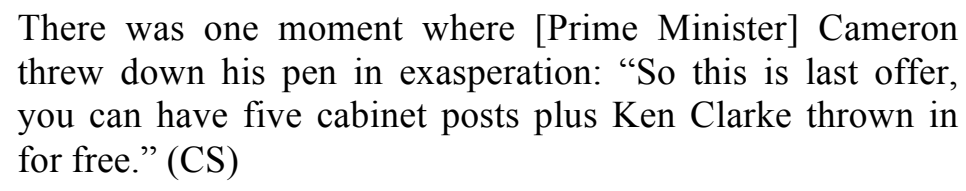

The novelty of coalition led to an obsessive focus by the news media on signs of a coalition split. On both sides, this added impetus to the desire by party leaders to, 'Hold the coalition together, try to present a united front' (LD). The Conservative prime minister sought to lead a government capable of pursuing successfully a coherent policy agenda (Laws, 2016: 432). For the Liberal Democrats, the need for the coalition government to succeed ran to the heart of the party's founding beliefs:

\footnotetext{
We regarded it as important to show that coalition could not only survive, but deliver good government too. If the public concluded that coalition was a bad idea, that could herald a return to two-party politics. (Baker, 2016: 255)
}

The novelty and uncertainties of coalition placed heavy demands on the civil service to demonstrate their ability swiftly to react to the altered political context. The primary response was a renewed formalizing of the policymaking machine. Cabinet 
government was revived; establishing and enforcing policy clearance procedures became crucial. The need for both coalition partners to sign off 'on every aspect of government policy' became a guiding principle (Hazell and Yong, 2012: 68). For officials, already complex existing practices and support systems for ministers had to be revised to ensure that one party was not being, nor seen to be, prioritized over the other:

It was important for us officials to ensure that we balanced the advice to all ministers... without any favours being shown to any individuals (CS).

One Liberal Democrat justice minister recalled that the atmosphere was 'rather collegiate':

You would go to a Cabinet committee, and you would not be able to, [if you were] an outsider, find out from who was taking which side in a particular discussion, which were the Liberal Democrats and which were the Conservatives (Lord McNally, Institute for Government, 2015: 6). ${ }^{15}$

However, Liberal Democrats conceded that it 'took a while to work out how to use the civil service machine' (LD). Further, the pressures of coalition and ministerial workloads made effective teamwork across the Liberal Democrat party as a whole very challenging:

Because [coalition] was new, because we were slightly surprised to be [in government], it took a time to start working collegiately across departments. And I suspect we never really did... (Lord McNally, Institute for Government, 2015: 5)

Efforts to tame the dilemmas posed by coalition saw issues relating to criminal justice largely 'parked' in the initial coalition agreement, in order to produce a document to which both parties could assent in a matter of days.

\footnotetext{
${ }^{15}$ The limits of collegiality were more often seen in the fractious relationship between fellow Conservatives (Laws, 2016: 273).
} 
I think [that] was indicative of the fact that perhaps it wasn't in the forefront of their minds at the point of negotiation, or certainly something they couldn't agree on things easily in that period (CS).

This lack of straightforward agreement, and the unexpected nature of the political appointments to the MoJ, prompted a pause and a (limited) reappraisal of penal policy.

Certainly Ken Clarke wasn't expecting to be [Justice Secretary] after May 2010. I certainly think that meant the ministers were very much back to square one in relation to, "Why are we here?" (CS)

This pause to reflect on penal policy was also informed by the buffeting of settled assumptions caused by the global financial crisis of 2008 and the emergence of austerity as a hegemonic global narrative (Crouch, 2011; Blyth, 2013). For over a decade British politics had ridden a wave of economic growth. It had been taken for granted that ongoing increases in public spending were possible and generally appropriate. Suddenly this had fallen away. The Conservative leadership had successfully cast the Global Financial Crisis as a Labour Party failure, caused by profligacy and irresponsible governance. In the face of alternative Keynesian policy proposals, the need for dramatic reductions in public spending took hold as the obvious and indisputably responsible policy position (Blyth, 2013).

While in many ways the Liberal Democrats were considered to have succeeded in their coalition negotiations, making gains on many of their favoured policy issues (Quinn et al., 2011), the Conservatives dominated on the economy, the rescue of which was the professed raison d'être of the Coalition. The Liberal Democrats agreed to the Conservative's more aggressive approach to deficit 
reduction, agreeing to cut $£ 6$ billion in the 2010-11 fiscal year and to eliminate the deficit within one parliamentary term (Hazell and Yong, 2012: 39).

Taken together, the twin dilemmas of coalition and austerity threatened to destabilize settled - largely adversarial and expansionist - assumptions:

You've got a new government, a coalition government, we've never had it before. It's trying to run its business in uncharted territories, it's got to make massive savings. (CS)

We have begun to see here policymakers' responses to the 'external' challenges of the period. In the following section I explore three key themes, which speak to the rationalities that were in play: deliberation, restraint and exclusion. In taming the uncertainties posed by coalition, we see that policymakers reached back for past practices. Where existing policymaking rationalities might have been radically destabilized, instead we see primarily resurrection and re-formalization.

\section{Policymaking rationalities and the coalition government}

\section{Deliberation}

Within the Ministry of Justice, and largely out of sight, a more reasoned and more reasonable approach to policymaking was considered to have emerged in the early years of coalition. This was an improvement in internal deliberation: intradepartment, cross-government and cross-party. One policymaker reflected that:

If you work through each of those pieces of legislation, with the exception of the knife crime provision, ${ }^{16}$ compromises and concessions were made to ensure things were squared within government, so the Deputy Prime Minister and Prime Minister, Chief Secretary, the Justice Secretary, signed off on

\footnotetext{
${ }^{16}$ In 2014, Justice Secretary Chris Grayling sought to legislate for a mandatory prison sentence for those prosecuted a second time for possession of a knife. Coalition agreement could not be reached but, via a backbench proposal, a form of the measure nonetheless eventually passed. It was one of few breaches of collective responsibility during the period of coalition government. See Laws (2016: 430431).
} 
a package of things that were tailored and measured to take account of that... [The process] tended to culminate in meetings where ministers would gather and talk through and try to thrash out the issues and the disagreements, and they would have their voices heard, and eventually a conclusion would be reached. $(\mathrm{CS})^{17}$

This view was shared by a Liberal Democrat policy participant:

I think the coalition had better criminal justice policy than a Tory majority government would have produced... the policy-making process was at times necessarily a process of negotiating between sharply different views, with each party wanting to secure specific policy gains and to block things it found unacceptable. (LD, unrecorded)

We have noted above the civil service efforts to re-formalize procedures, to return to more traditional modes of Whitehall governance. In contrast with highlycriticised moments in penal policymaking during the preceding Labour government it was considered that in particular in the sentencing field,

It wasn't simply a matter of just bulldozing [policy] through a clearance process because the Home Secretary wants this to happen. You needed to persuade people. That was actually quite a refreshing change (CS).

The re-prioritization of internal deliberation and accord gave renewed significance to existing procedures such as the departmental 'write around':

If we're not able to negotiate and able to get it right [within the department], we [would] say, "Look, this is as much as we're able to do internally. You're welcome to write round and I think other people in other departments will have concerns with it"...[Then the Justice Secretary] writes to every single cabinet minister and says, "This is what I propose to do". Now, this is where the Liberal Democrat advisers were... able to pull the second lever at our disposal: speaking to the special advisers for senior Liberal Democrats and [getting them to say], "These are our problems with this policy and these are the things we would like to change". (LD)

\footnotetext{
${ }^{17}$ See also Baker (2016: 256).
} 
While procedures such as this were of utility to the minority coalition partner, the Liberal Democrats were hindered in a number of ways. A cross-party agreement to limit the numbers of special advisers caused severe problems for Liberal Democrat ministers (Hazell and Yong, 2012: 46). Further, the 'short money' provided to opposition parties was withdrawn from the Liberal Democrats, leaving them substantially weakened in terms of the number of policy advisers that they could afford to employ (LD).

The response to coalition was considered, in other words, to have promoted a fuller airing of internal debates. It worked 'well, and a lot better than the previous unofficial coalition between the Blairites and the Brownites had' (Baker, 2016: 256). ${ }^{18}$ The good inter-party and intra-departmental relations were no doubt helped by Justice Secretary Ken Clarke being widely perceived to be 'more liberal than most liberals' in terms of social policy (CS). ${ }^{19}$ Indeed, coalition sceptic Ken Clarke was surprised to conclude that coalition, and the involvement of the Liberal Democrats, 'greatly assisted' his efforts to challenge the existing 'prison works' paradigm (Clarke, 2016: 445).

The improved internal deliberation was warmly welcomed by civil servants. Some considered that this was supported by improvements that had been made in their ability to provide evidence-based advice to support policy development:

I think during the coalition, there certainly were requests for evidence behind some of the policy making. Helpfully the [department] has upped its game in relation to some of its analysis that it does, so it's a bit more nimble and able to at least take a view on some of these things. (CS)

\footnotetext{
18 'Blairites' and 'Brownites' refers to the warring factions within the 1997-2010 Labour government.

${ }^{19}$ Equally, Clarke was a strident economic liberal who heavily favoured market-oriented reform.
} 
For civil servants, coalition meant greater clarity and consistency: policies had to be openly debated and agreed by both coalition parties. The civil service were empowered, 'encouraged to intervene in Whitehall policy debates, and to offer more evidence and advice' (Hazell and Yong, 2012: 67). Their voice was (more often) heard; their role (somewhat) restored.

Looking beyond the department, policy participants had been encouraged by the early statements of the coalition government Justice ministers. They recognised that, as ever, 'it is those early days which are quite crucial...you want to set the direction early on and be part of that' (Ch). A range of reports seeking to inform government policy duly emerged in $2009-2010 .^{20}$ There appeared to be greater openness by the Ministry of Justice to such interventions, and to dialogue with a number of policy participants.

Policy was viewed by some as having been developed in a more appropriately deliberative, considered manner, in particular during the Clarke era:

I think Ken Clarke, being a lawyer... realised that he had to take people with him and nothing moves quickly in the criminal justice world. His [measured] pace, taking people with him, and his consultations and his pilots and so on was a very sensible way. $(\mathrm{Pa})$

It was, in other words, considered by many policy participants that Ministry of Justice policymakers' response to the dilemmas of coalition and austerity had led to improved deliberation within the department, and also to some level of improved engagement with (some) informed individuals and groups without the department.

Taken together, a civil servant summarised the approach to policymaking during this period thus:

\footnotetext{
${ }^{20}$ See, for example, Jacobson and Hough (2010) and Commission on English Prisons Today (2009).
} 
There was certainly a sense of being able to at least start in relation to where are we, where do we want to be, and the fact that it took a good two years to legislate [LASPO 2012] was perhaps quite a healthy sign in relation to the thought to work through those positions quite carefully, which included discarding some policies which were not going to fit with what they could afford to do going forward. (CS)

\section{Restraint}

At the halfway point of the UK coalition government, coalition appeared to observers to be providing some degree of 'relative insulation from populist and adversarial law and order politics' (Lacey, 2012: 235). This was arguably borne out by trends in the prison population seen over the period of the coalition government. Between December 2012 and May 2015, the overall population never fluctuated by more than $1.3 \%$, and at times fell below the 2010 level, halting the substantial rises seen since 1990 (Allen and Dempsey, 2016: 6).

Policymakers were operating under a clear governmental steer on the primacy of the austerity agenda.

I think what was pretty clear and evident in the early part [of the 2010-15 government], perhaps it was austerity that caused it, was that people were much more concerned about the cost of our penal policy (CS)

Concerns about the costs of penal policy were not new; throughout the New Labour period, the Treasury had sought to limit future criminal justice spending. However, such efforts had persistently been undermined by Prime Minister Tony Blair's desire for ever-more expansive criminal justice intervention. There had developed an underlying assumption that 'you could not explicitly articulate the tradeoffs' between the desire severely to punish offenders and the need to manage scarce resources responsibly (CS). 
By contrast, policymakers' (re-)establishment of formal procedures in order to respond to the dilemmas posed by coalition required the financial implications to be addressed head-on. The Liberal Democrat leader's position as Chair of the Home Affairs Cabinet Committee, where policy announcements could not happen 'until he has signed the clearance letter' (Cabinet Office official, quoted by Hazell and Yong, 2012: 54) gave such deliberations a particularly hard edge. This meant that:
A number of the provisions that we took forward were more balanced and took greater account, for example, of judicial discretion because the Lib Dems were there to say, "But have you thought about this?"...it probably overall resulted in a more balanced package. (CS)

In other examples of recent emergences of coalition government, such as New Zealand, criminal justice policy has at times been 'given up' by the majority coalition party in order to enable them to maintain control of their overall socio-economic agenda (Lacey, 2012: 219). In this case, by contrast, the majority Conservative coalition partner held the dominant position in relation to criminal justice throughout the $2010-15$ period.

The latter, Grayling, era was far more turbulent, and policy developments far more heavily criticized. On the face of it, restraint was in short supply. Probation marketization was pursued at a hectic pace, and for many critics in an acutely reckless manner. ${ }^{21}$ Dramatic cuts to prison resources and staff numbers were driven through with severe consequences (HM Chief Inspector of Prisons, 2017). Liberal Democrats, outnumbered and outgunned within government and the Ministry of Justice, and now bereft of a (socially) liberal Justice Secretary who shared many of their goals, were unable to challenge this agenda. Where there were policy differences, Liberal

\footnotetext{
${ }^{21}$ See ‘Transforming Rehabilitation’ special issue, British Journal of Community Justice 11(2-3).
} 
Democrats could, at best, seek to act as something of a brake, 'to stop policies going in an illiberal direction' (LD, unrecorded).

However, this starkly altered trend, putting 'rocket boosters' under developments cautiously set in train by Clarke (Garside and Ford, 2015: 19), was matched by continued restraint in sentencing. This was in part because the dynamics under Justice Secretary Grayling were very much 'transactional':

[Justice Secretary Grayling] had his probation reforms and that's all that he wanted to do. It became much more, "I'm going to do this, but in return I won't stand in your way to do something else." (LD)

This was also due to the ongoing importance of the activities (and therefore the underlying rationalities and practices) of civil servants to policymaking. A particularly striking indication of the centrality of senior civil servants to the course of penal policy is provided by the following recollections on the very early days of the coalition government:

If you think about how quickly we did all this, it was kind of crazy...In the Programme for Government, when the coalition was agreed, [senior civil servants] made sure that there were two key reviews, as they were called, put into the Programme for Government. One was on legal aid, because that was such a big area for us to attack for savings. And the second was on, I think it was called a review of sentencing...And again, there wasn't clarity at that point [about] what it was we were seeking to achieve - other than needing those two hooks in the Programme for Government to enable us to get on with it. We were doing that in that wonderful week in between, when we didn't actually know what the government was going to be. We were feeding into the centre that, whatever the outcome of the negotiations, whoever was forming the government needed these two things - from [the department's] point of view. (CS, emphasis added)

Senior civil servants, acutely aware of the clear political signals regarding the upcoming austerity agenda, were seeking to act as responsible guardians for the 
department even before the coalition had been formalized. And this mentality was maintained throughout for the majority of policy issues (the Transforming Rehabilitation agenda being a notable exception). One civil servant manifested this guardianship role when noting with satisfaction, that coalition penal policymakers had 'got their head into a good housekeeping place' (CS).

As one civil servant recalled, policymaking was conducted with a much more explicit recognition of the need to operate within the resourcing constraints agreed by the department and closely enforced by the Treasury:

If you have a thousand places, where do you want to "spend" those thousand places? Do you want to spend them on this category of offender - sex offenders, serious violent offenders? Or do you want to spend them elsewhere? Government had to make a decision in relation to where does it spend its limited room for manoeuvre that it has. (CS)

In relation to sentencing, in particular, civil servants engaged with politicians in a good deal of 'backstage work' in order to ensure that the 'frontstage' performative requirements of political discourse were achieved without deleterious substantive impacts upon the penal system. ${ }^{22}$ Notwithstanding the apparent dramatic change of course from Clarke to Grayling, for the most part civil servants continued to engage in a traditional form of 'damage control' (Loader, 2006: 569), with ministers being given 'some interesting political stories' (CS), some 'tabloid-friendly' measures (LD), which were designed not to have 'much effect on the overall prison numbers' (LD).

The restraint observed here therefore speaks not to the potentially synonymous notion of moderation, in the sense of a set of considered policy positions underpinned by a detailed public philosophy of punishment (Loader, 2010). Rather, it speaks to the

\footnotetext{
${ }^{22}$ On the application of Goffmann's sociological notions of 'frontstage' and 'backstage' to political activity, see Wodak (2012).
} 
quotidian dynamics of resistance (and enablement) in play, driving policymakers towards certain policies (in certain forms) rather than others. These dynamics come into even sharper focus in the following section.

\section{Exclusion}

A recurring, and countervailing, theme of policymakers' experiences of penal policymaking under the coalition centred upon exclusion: both of people or groups (ie the exclusion of 'outsiders') and of ideas (a refusal to expand what we might term the penological imagination). As regards the former, there was consternation at a department that was considered by some to have, in fact, become more insular and exclusionary during this period.

Reflecting upon Clarke's early speeches on prison reform, one policy participant recalled that:

Clarke gets up and speaks about [reform] and it's appealing to a liberal viewpoint, quite refreshing to hear from the Conservatives. But there was no substance to it. And the only substance that was to be applied was from senior civil servants in the system. It was, "There's the brief. Go and make of that what you will." (Ch)

This exclusionary disposition was also felt keenly by third sector groups:

During the period of the coalition... the dislike of critical voices, and particularly the feeling that that's not the charity sector's role, is quite a consistent view across the Conservative party. Both [Justice Secretaries], I think [took the] view, especially if you're taking government money, that you need to shut up and deliver what we've asked you to deliver. (Ch)

Traditional hierarchies tended to remain. For example, under Clarke, the department was generally receptive to concerns of senior judges in relation to sentencing matters (see Clarke, 2016: chapter 24); under Grayling there was neither 
the 'interest', nor did he possess the standing, for their arguments to be challenged robustly (Con). By contrast, it was considered by many policy participants that the sidelining and exclusion of the critical voices of practitioners, academics, reform groups and unions - groups whose influence on policymaking has been highly variable, and often increasingly tenuous, over recent decades (Ryan et al., 2001) was particularly acute during the coalition period.

This insularity was, in part, a corollary of improved internal deliberations, civil servants successfully 'getting the right policy agreed within the coalition and ensuring it was affordable' (CS). This more sustained focus on internal agreement tended to mean that 'all of the concessions that you would normally have made as part of the legislative process, we were making internally, in government' (CS).

\footnotetext{
What [coalition] did I think mean was when you took those provisions to Parliament, generally speaking people did hold the line... I think once you'd brokered that agreement at the centre it did hold... once you were taking that legislation through (CS)
}

This internalization of debate that would usually more fully be aired in the Houses of Parliament suggested for one observer that, 'Counter-intuitively, the impact of Coalition was to shut the reformers up' (CS).

I do not seek to claim that evidence was never utilized, nor that forms of expertise were never drawn upon. Work on police cautions was one indicative counter-example raised in interviews: ${ }^{23}$

[Ministers] were persuaded to do a piece of work in relation to an evidence base... which influenced the decision making process. But...we were asked to do that review in six to eight weeks, It wasn't a detailed [review]...the emphasis was on speed and getting this done quickly so that they could make decisions to feed into their legislative approach. (CS)

\footnotetext{
${ }^{23}$ See Siddique (2013).
} 
Another example given was the effort better to respond, in a co-ordinated fashion, to the need to address the logjam of IPP prisoners struggling to progress towards release (Annison, 2015: Chapter 7).

However, these efforts were seen to have been rather exceptional. High-profile policies, including the criminal courts charge and the Transforming Rehabilitation agenda, were striking demonstrations of tendencies that encompassed an unwillingness to seek out (particularly opposing) evidence or expert views and, equally, a political desire selectively to draw upon supportive think-tanks to bolster the case for preferred reforms. The criminal courts charge was highlighted as one particularly egregious example of these trends:

[A] very poorly thought through policy that superficially ticked a number of boxes which needed to be ticked. So one around, yes, we can magic hypothetical savings through it, and then the other, it... will be popular, you know, to make criminals pay. (Ch)

While these concerns spanned the coalition period, the exclusion of evidence and expertise was felt particularly acutely, to have been 'particularly difficult' (LD), during the Grayling era:

The sense under [Justice Secretary] Grayling was that the department had essentially battened down the hatches, they were going to pursue their core policies regardless, they didn't really want to hear conflicting points, any view that said, "Don't do this" or "Slow down". (CS)

From the perspective of some political actors, the civil service's efforts to ensure that proper processes were followed (and to be mindful of the financial reductions required) may have served to restrain the substantive impact of the Grayling era's punitive rhetoric. But it also demonstrated for some 'a system engineered to resist change' (Clegg, 2016): 
Every time we would suggest [a new policy], they'd come back with 20 reasons why we can't do it and just the idea of doing something slightly differently was hugely problematic [for civil servants]. (LD)

These frustrations were not limited to Liberal Democrat actors; ambitious Conservatives also found progressive reform to be 'extraordinarily difficult' (Con):

[Civil servants] had got better at understanding the drivers of demand. They're still not there, but they got better. But any reform was like pulling teeth. (Con)

Coalition could have supported a fundamental reassessment of the manner of political debate around criminal justice issues, given that both parties shared a stated goal of being, in short, 'smarter' rather than ever 'tougher' on crime (Conservative Party, 2008; Liberal Democrats, 2010). The steep decline in recorded crime since the mid-1990s, ${ }^{24}$ coupled with the substantial resource cuts required of criminal justice agencies and the penal system, could have added further assistance.

Being 'tough on crime' seemed to be becoming a 'debased currency' (Downes and Morgan, 2012: 203), with the media's attention (and intensity of demonizing focus) increasingly re-trained upon other targets such as immigration (Downes and Morgan, 2012: 203). Finally, the durability afforded to government by the FixedTerm Parliament Act and the parliamentary majority enjoyed by the coalition government could further have been expected to support such efforts.

However, the fall in crime remained 'one of the biggest untold success stories of this coalition' (Clegg, 2014). Notwithstanding the apparent changes in the political landscape, and the assertions to the contrary noted above, many coalition political actors felt very much affected (and angered) by the Labour opposition's decision to

\footnotetext{
${ }^{24}$ The extent to which crime statistics reflect the true level of criminality, in particular given the rise of online crime, remains a hotly contested topic.
} 
'surrender' to the temptation to paint Ken Clarke's penal reductionist proposals as unworkable and dangerous.

Labour started playing politics with criminal justice, in particular [Shadow Justice Secretary] Sadiq Khan. I'm not sure I'll ever forgive him for screwing us over. He made it such a nightmare. (LD)

The visceral fear of being labelled 'soft on crime' persisted.

Policy participants' overriding tone was therefore one of frustration and regret. One civil servant considered that while the early years of the coalition featured improved deliberation and moderation, even at that early stage the political die had been cast. Policy areas never stand alone; they sit within complex considerations of prioritization, 'balance' and the expenditure of political capital. The leadership's focus was largely elsewhere. So the messaging swiftly became, 'Take your foot off the gas'; be sure to 'throw some red meat to the [Conservative backbench MPs]' (Con).

The momentum generated by the Conservatives in opposition for a programme of penal policy reform was delayed and disordered by the disruptions of coalition. Equally, the conversation that Justice Secretary Clarke had sought to develop around the appropriate level of imprisonment in the early days of coalition:

Was completely blocked and [the Justice Secretary] was then moved to be cabinet minister without responsibility for anything. (CS) ${ }^{25}$

This period, therefore, was - for both Conservative and Liberal Democrat political actors who desired joined-up, and in their view progressive, action on penal policy - 'at times, a fucking miserable experience. It was a constant battle to get anything done' (Con).

\footnotetext{
${ }^{25}$ See also Rawnsley (2014).
} 
There was a chance for real progressive reform, sentencing reform and prison population reductions. Had [Prime Minister] Cameron remained strong on it, real progress could have been made. He could have said, "This is a mandate I've been elected on. We're trying to balance the books, we want to get people out of prison. We can do that by limiting sentencing and improving rehabilitation." But it fell apart once Number 10 lost their nerve. (LD)

Liberal Democrats recalled that they were, under these conditions, able to make some headway in some less contentious areas of policy. ${ }^{26}$ The controversial changes to probation received Liberal support. There was a sense that 'less impotent shouting from the sidelines' occurred; there was 'more actual change' as a result of being 'part of the system' (LD). Nonetheless, the dynamics that supported resistance to 'the unquestioning acceptance of higher sentences as an automatic response to crime' (LD, unrecorded interview) also served to make introducing new policies 'extremely difficult' (LD).

Policy objectives were thus swiftly attenuated:

You could pick a fight all day long about prison numbers, but...if we're not going to deliver anything at the end of it, what's the point? What are we actually in government for? It's to deliver policy. (LD)

Overall, many policy participants considered that the policymaking rationalities emerging from the response to coalition had served to mitigate somewhat the extent to which regressive rhetoric on sentencing and punishment could be converted into substantive action. However, the same rationalities also served actively to undermine the potential for strong voices to emerge on penal reform:

Because [the Liberal Democrats] were in the Coalition, at one level a distinctive liberal voice was silenced by the requirements of the Coalition. And actually it's out of Coalition that they are freed up to speak more freely, to advance policy on their own account. (CS)

\footnotetext{
${ }^{26}$ Examples given usually centred upon women in prison, restorative justice and youth custody.
} 
In sum, therefore, the response to the dilemmas of coalition saw policy participants drawing upon, and (re-)establishing traditional, formal modes of policymaking that generally improved the quality and transparency of internal debates. However, the external debate was considered to have remained little changed. The electorally-oriented, instrumentally punitive rationality of the previous decades - and the exclusionary rationalities therein - retained a firm hold.

\section{Change, Continuity and Enduring Rationalities of Penal Policymaking}

This paper has explored how policy participants responded to the highly unusual need to develop policy within an explicit coalition framework, as a specific instance of the broader question of how penal policymakers interpret, rationalize and thereby instantiate 'external' change. Drawing on first-hand accounts of the period, I have considered how penal policymakers sought to manage the uncertainties of this period and thus how the implications of the coalition dilemma were integrated within - or served to reshape - the extant rationalities on which penal policymaking was predicated.

A critical reconstruction of this period has centred upon three interweaving themes: deliberation, restraint and exclusion. We have seen that internal deliberation negotiations within and between parties, departments and government - was generally considered to have improved as a result of the practices that became dominant as a response to coalition. Further, the emergent dynamics of coalition (and the reformalization of policymaking rationalities), coupled with the pressures imposed (and, thereby, the 'tools' provided) by political choices around austerity, tended to act as a restraining force on penal policy. 
Throughout the period, coalition was responded to, and utilized by, policy participants in a manner that served to restrain efforts to achieve a step-change in penal policy in any direction (be that liberal, reductionist, progressive or punitive). Probation marketization and prison resourcing served as important exceptions to this trend. Where civil servants sought to act as a traditional 'drag anchor on the impulses of elected politicians' in relation to sentencing (Loader, 2006: 568), the dominance of the 'monomaniacally' obsessed Justice Secretary Grayling (Con and LD) - in a manner strikingly similar to more traditional patterns of recent decades of single party government - saw the probation landscape dramatically altered.

Ultimately, the coalition period was characterised by exclusion. Though seen most clearly in the latter Grayling era, an inward-looking exclusionary approach to potential policy participants equally served, ironically, to underpin the initial relatively progressive period of policy development. The 're-formalizing' of the machine, the taming of the uncertainties created by coalition, served to encourage the exclusion (or at best partial, instrumental utilization) of many external individuals, groups and ideas.

In the face of the dilemma of coalition, and influenced by political choices relating to austerity, policymakers' response was to re-formalize internal policymaking processes, establishing not novel and innovative, outward-looking mechanisms but in fact resurrecting older, more traditional forms of policy development and government. This maintained, and perhaps in some regards even increased, the tendencies of centralization and insularity in English penal policymaking. By the close of the 2015 government, coalition had been tamed: traditional, durable exclusionary rationalities took centre stage. 
A number of broader lessons can be drawn. It is clear that we should not expect structural change - be that changes to an electoral system, political structures, dramatic changes to the economy, and so on - to have a linear, nor necessarily an immediate (Farrall and Hay, 2010), effect. Policymakers wrestle with the dilemmas posed by 'external' change to make them manageable, be that by re-shaping existing rationalities and practices, re-shaping the dilemma so as to fit within existing rationalities and practices, or a combination of the two. In this iterative process policymakers can manage and even proactively utilise developments such as the emergence of coalition government, but at the same time are themselves potentially constrained and channelled by (other policy participants' reaction to) them.

Other considerations are always in play: concerns about internal party management, about the expenditure of political capital, and so on. Decisions about policy are heavily conditioned and constrained - or indeed, at times propelled - by prior ongoing decisions regarding policymaking. Indeed, we have seen that for policymakers these two considerations - policy-as-process, and policy-as-output - are inextricably linked.

We have further seen that individuals and the internal dynamics of political parties are highly influential on policy change. Relatively minor contingent events the selection of one minister over another, an inadvisable statement in a media interview - can have a considerable effect. In this specific case, it is entirely plausible to suggest that significant developments - the size of the prison population, the configuration of probation services and so on - might have proceeded in very different forms had a number of minor contingencies operated in slightly different ways. 
There exists in any particular political context, therefore, a complex interaction between conditions 'out there', the rationalities and practices of specific individuals, and eventual policy outcomes. To return to the specific question of coalition government and penal change, rather than asking, 'How does coalition government shape penal policy in different electoral systems?' we can better ask, 'How have policy participants interpreted and acted upon the dilemma of coalition government in a specific location and context, or how might they do so?'

In the English context, the exclusionary rationalities identified here continue to persist. Prisons Inspectorate reports have repeatedly documented the startling deterioration in prison conditions that have resulted from the policy decisions of the coalition government (HM Chief Inspector of Prisons, 2017). Suicides, self-harm and assaults continue to rise (Prison Reform Trust, 2016).

It has rightly been observed that 'the urgency of the issue' must be 'matched by the vigour of the response' (HM Chief Inspector of Prisons, 2017). Despite, or perhaps because, of the seemingly relentless political turbulence in which (penal) policymaking currently operates, there are no indications that a suitably urgent - and appropriately inclusive - programme of action is likely to emerge. The exclusionary rationalities of penal policymaking continue to endure.

\section{Funding}

This work was supported by a Southampton Law School Research Fund grant.

\section{Acknowledgments}

Earlier versions of this paper were presented at the British Society of Criminology annual conference (Sheffield, 2016), the Oxford University Centre for Criminology 
informal seminar series, and the Sheffield University Centre for Criminology Research seminar series. I am grateful to the attendees on each occasion for their thoughts and comments. Thanks also to Ian Loader, Richard Martin, David Gurnham, and to the anonymous peer reviewers for comments on earlier drafts.

Bibliography

Allen G. and Dempsey N. (2016) Prison Population Statistics. London: House of Commons Library.

Annison H. (2015) Dangerous Politics, Oxford: Oxford University Press.

Annison H. (Forthcoming) Towards an Interpretive Political Analysis of Penal Policy. Howard Journal of Crime and Justice.

Baker N. (2016) Against the Grain, London: Biteback Publishing.

Bastow S. (2013) Governance, Performance, and Capacity Stress, Basingstoke: Palgrave Macmillan.

Bell E. (2011) Criminal Justice and Neoliberalism, Basingstoke: Palgrave Macmillan.

Bevir M. and Rhodes R. A. W. (2010) The State as Cultural Practice, Oxford: Oxford University Press.

Blunt C. (2010) Speech to the All-Party Parliamentary Penal Affairs Group 6 July 2010. London: Prison Reform Trust.

Blyth M. (2013) Austerity, Oxford: Oxford University Press.

Cameron D. (2011) Press Conference on Sentencing Reforms. Available at: https://www.gov.uk/government/speeches/pms-press-conference-onsentencing-reforms.

Cavadino M. and Dignan J. (2007) The Penal System, London: SAGE Publications.

Clarke K. (2016) Kind of Blue, London: Macmillan.

Clegg N. (2014) The Rehabilitation Revolution. London: Cabinet Office.

Clegg N. (2016) Politics: Between the extremes, London: Bodley Head.

Commission on English Prisons Today. (2009) Do Better Do Less. London: Howard League for Penal Reform.

Conservative Party. (2008) Prisons with a Purpose. London: Conservative Party.

Crouch C. (2011) The Strange Non-Death of Neoliberalism, Cambridge: Polity.

Downes D. and Morgan R. (2012) Overtaking on the Left? In: Maguire M., Morgan R. and Reiner R. (eds) The Oxford Handbook of Criminology. Oxford: Oxford University Press. 
Farrall S. and Hay C. (2010) Not so Tough on Crime? Why weren't the Thatcher governments more radical in reforming the criminal justice system? The British Journal of Criminology 50: 550-569.

Flyvbjerg B. (2006) Five Misunderstandings About Case-Study Research. Qualitative Inquiry 12: 219-245.

Garside R. and Ford M. (2015) The Coalition Years. London: CCJS.

Hazell R. and Yong B. (2012) The Politics of Coalition, Oxford: Hart Publishing.

Herbert N. (2010) Speech to the Howard League for Penal Reform. London: Howard League for Penal Reform.

HM Chief Inspector of Prisons. (2017) Annual Report 2016-7. London: TSO.

HM Inspectorate of Prisons and HM Inspectorate of Probation. (2017) An Inspection of Through the Gate Resettlement Services for Prisoners Serving 12 Months or More. London: HM Inspectorate of Probation.

Institute for Government. (2015) Ministers Reflect: Lord McNally. London: Institute for Government.

Jacobson J. and Hough M. (2010) Unjust Deserts. Prison Reform Trust,.

Jones T. and Newburn T. (2007) Policy Transfer and Criminal Justice, Maidenhead: Open University Press.

Lacey N. (2008) The Prisoners' Dilemma, Cambridge: Cambridge University Press.

Lacey N. (2012) Political Systems and Criminal Justice: The prisoners' dilemma after the coalition. Current Legal Problems 65: 203-239.

Laws D. (2016) Coalition, London: Biteback Publishing.

Liberal Democrats. (2010) Liberal Democrat Manifesto. London: Liberal Democrats.

Loader I. (2006) Fall of the 'Platonic Guardians': Liberalism, criminology and political responses to crime in England and Wales. British Journal of Criminology 46: 561-586.

Loader I. (2008) Review Symposium: The anti-politics of crime. Theoretical Criminology 12: 399-410.

Loader I. (2010) For Penal Moderation: Notes towards a public philosophy of punishment. Theoretical Criminology 14: 349-367.

Loader I. and Sparks R. (2004) For an Historical Sociology of Crime Policy in England and Wales since 1968. Critical Review of International Social and Political Philosophy 7: 5-32.

Marshall P. and Laws D. (2004) The Orange Book: Reclaiming Liberalism, London: Profile.

McAra L. (2008) Crime, Criminology and Criminal Justice in Scotland. European Journal of Criminology 5: 481-504.

Ministry of Justice. (2010) Breaking the Cycle: Effective punishment, rehabilitation and sentencing of offenders. London: TSO.

Ogg J. (2015) Preventive Justice and the Power of Policy Transfer, Basingstoke: Palgrave Macmillan.

Pratt J. and Clark M. (2005) Penal Populism in New Zealand. Punishment \& Society 7: 303-322.

Prison Reform Trust. (2016) Bromley Briefing: Summer 2016. London: PRT.

Quinn T., Bara J. and Bartle J. (2011) The UK Coalition Agreement of 2010: Who won? Journal of Elections, Public Opinion and Parties 21: 295-312.

Randall N. (2004) Three Faces of New Labour: Principle, Pragmatism and Populism in New Labour's Home Office. In: Ludlam S. and Smith M. J. (eds) Governing as New Labour : policy and politics under Blair. Basingstoke: Palgrave Macmillan. 
Rawnsley A. (2014) Kenneth Clarke: I had a lot of views, but they didn't coincide with No 10's. The Observer. London/Manchester: Guardian News and Media Limited.

Reiner R. (2017) Political Economy, Crime and Criminal Justice. In: Liebling A., Maruna S. and McAra L. (eds) Oxford Handbook of Criminology. Oxford: Oxford University Press.

Rhodes R. A. W. (2011) Everyday Life in British Government, Oxford: Oxford University Press.

Rock P. E. (2004) Constructing Victims' Rights, Oxford: Oxford University Press.

Rogan M. (2011) Yes or No Minister: The importance of the politician-senior civil servant dyad in Irish prison policy. The Prison Journal 91: 32-56.

Ryan M., Savage S. P. and Wall D. (2001) Policy Networks in Criminal Justice, Basingstoke: Palgrave.

Seldon A. and Snowdon P. (2016) Cameron at Number 10, London: William Collins.

Siddique H. (2013) Police Cautions to be Reviewed by Government. The Guardian.

Silvestri A. (2011) Lessons for Coalition, London: CCJS.

Skinns D. (2016) Coalition Government Penal Policy 2010-2015, Basingstoke: Palgrave Macmillan.

Stratton A. (2010) Tories to Invoke Churchill in Defence of Changed Tack on Prisons. The Guardian. London/Manchester: GMG.

Wacquant L. (2009) Punishing the Poor, Durham, NC: Duke University Press.

Wagenaar H. (2011) Meaning in Action, Abingdon: Routledge.

Wodak R. (2012) Politics as Usual: Investigating political discourse in action. In: Gee J. P. and Handford M. (eds) The Routledge Handbook of Discourse Analysis. Abingdon, Oxon: Routledge. 